\title{
IL-3 does not affect the allergic airway responses and leukotriene production after allergen challenge in rats
}

\author{
T. Du*, J.G. Martin*, L.J. Xu*, W.S. Powell ${ }^{+}$P.M. Renzi*,+
}

\section{IL-3 does not affect the allergic airway responses and leukotriene production after allergen challenge in rats. T. Du, J.G. Martin, L.J. Xu, W.S. Powell, P.M. Renzi. (C) ERS Journals Ltd 1999.}

ABSTRACT: T cell cytokines are important in asthma. Interleukin (IL)-3, an important growth factor for mast cells and eosinophils has been shown to be increased in the airways of asthmatic subjects, but its precise functions are uncertain. The aim of this study was to determine whether recombinant human (rh) IL-3 affected airway responses, inflammation and leukotriene production after antigen challenge in Brown Norway (BN) rats.

Having established that rhIL-3 (>12.5 $\mu$ g subcutaneously b.i.d. for 4 days) caused a doubling of mast cell numbers in the airways of $\mathrm{BN}$ rats, sensitized rats were pretreated with rhIL-3 $(50 \mu \mathrm{g})$ or vehicle subcutaneously b.i.d. for 4 days. Ovalbumin (OA) challenge was performed and the early (EAR), and late (LAR) airway response and the associated biliary leukotriene (LT) excretion measured. The pulmonary cellularity was evaluated by means of lung digestion $8 \mathrm{~h}$ after challenge.

IL-3 increased the number of eosinophils isolated from the lungs after antigen challenge $\left(0.77 \pm 0.23\right.$ versus $0.38 \pm 0.12 \times 10^{6}$ cells, $\left.p=0.03\right)$. However, there were no effects on the numbers of neutrophils, lymphocytes and macrophages. Neither the EAR nor the LAR after OA challenge were altered by IL-3. Likewise biliary cysteinylLT excretion was similar in IL-3-treated animals and controls after challenge.

In conclusion, interleukin-3 caused an increase in the numbers of mast cells and eosinophils around the airways without affecting the magnitude of either early or late airway responses or mediator release after antigen challenge. The present results suggest that airway inflammation can occur in rats without increasing the allergic asthmatic response.

Eur Respir J 1999; 13: 970-975.

\begin{abstract}
*Meakins-Christie Laboratories, Royal Victoria Hospital, McGill University and the ${ }^{+}$University of Montreal affiliated Hospitals Research Center, Montreal, Quebec, Canada.
\end{abstract}

Correspondence: P.M. Renzi, MeakinsChristie Laboratories, McGill University, 3626 St Urbain Street, Montreal, Quebec H2X 2P2, Canada, Fax: 15143987483

Keywords: Eosinophils

interleukin-3

late response

leukotrienes

mast cells

Received: July 171998

Accepted after revision January 71999

This study was supported by grant No. MT-10381 of the Medical Research Council of Canada, the Research foundation of the CHUM hospital and the E/L J.T.C. Memorial Research Fund. P.M. Renzi is the recipient of a Chercheur Boursier award from the Fonds de la Recherche en Santé du Québec.
Allergic asthma is generally considered an immunoglobulin (Ig)E-mediated inflammatory disease of the airways [1]. Studies of the pathogenesis of allergic asthma have shown that mast cells, eosinophils and T-lymphocytes are present in increased numbers in the airways of asthmatics and are potentially important contributors to the physiological changes which occur in this disease [2]. The concept that allergic airway inflammation is uniquely driven by mast cell-derived products has been modified by recent advances in the understanding of the function of T-lymphocytes. The T-lymphocyte also has a role in allergic airway inflammation in view of its functions in the regulation of $\mathrm{IgE}$ production and via the production of cytokines $[3,4]$, which can upregulate the number or activation state of eosinophils and mast cells.

Several T-lymphocyte cytokines have been shown to be increased in asthmatic airway inflammation, including interleukin (IL)-4, IL-5 and granulocyte macrophage colonystimulating factor $[4,5]$. The concentrations of these cytokines also increase in the airways after antigen challenge [5] and may be involved in the persistent inflammatory changes and physiological abnormalities that have been described in asthma. IL-3 is a cytokine secreted by CD4+ T-lymphocytes that has the capacity to induce activation and proliferation of mast cells and eosinophils [6-8]. IL-3 can induce the release of histamine in basophils, either directly or when added with antibodies directed against-IgE [9]. IL-3 production is increased in mononuclear cells obtained from atopic patients and stimulated with antigen [10], and IL-3 messenger ribonucleic acid (mRNA) expression is increased in CD4+ lymphocytes obtained from the blood of individuals with severe asthma [11]. Although IL-3 mRNA expression is increased in the airways [12] and IL-3 itself is increased in the intestinal mucosa of patients with asthma [13], IL-3 was not found to be increased in the airways of patients with asthma [14]. Whether or not IL-3 levels are increased, its potential effects in asthma remain controversial, and no information is available as to whether IL-3 affects the airway response to antigen.

The present experiments addressed whether or not the induction of airway inflammation with IL-3 affected allergic airway responses. Sensitized Brown Norway (BN) rats were treated with recombinant human (rh) IL-3, with the objective of increasing mast cell numbers around the airways, and then challenged with antigen. Since the magnitude of bronchoconstriction induced by inhaled allergen is a function of the amount of cysteinyl-leukotrienes (LTs) 
synthesized within the lung, biliary LT excretion after antigen challenge was also examined. Various workers have shown that cysteinyl-LT levels increase in the bile of the rat after allergen provocation $[15,16]$ and therefore provide a valuable estimate of the magnitude of the immunological response that has been evoked.

\section{Materials and methods}

\section{Animals and sensitization}

Thirty-eight male BN rats, 7-8-weeks-old and weighing 150-192 g, were actively sensitized by means of a single subcutaneous injection $1 \mathrm{mg}$ ovalbumin (OA) and $200 \mathrm{mg}$ aluminum hydroxide. Simultaneously, $1 \mathrm{~mL}$ of Bordetella pertussis vaccine, containing $6 \times 10^{9}$ heat-killed organisms, was given intraperitoneally as an adjuvant. Animals were treated and cared for in accordance with the guidelines formulated by the National Society for Medical Research (USA).

\section{Study design}

rhIL-3 was kindly provided by Novartis (Basle, Switzerland). IL-3 (4.8 mg) was diluted with $30 \mathrm{nM}$ citric acid $(\mathrm{pH} 7)$ to a final concentration of $100 \mu \mathrm{g} \cdot \mathrm{mL}^{-1}$. The endotoxin concentration was calculated to be $<1 \mathrm{ng} \cdot \mathrm{mL}^{-1}$ after dilution, a level that did not affect inflammation or physiological responses in previous experiments $[17,18]$. For experiments necessitating a lower concentration of IL-3, $0.2 \mathrm{mg}$ was diluted to a final concentration of 25 $\mu \mathrm{g} \cdot \mathrm{mL}^{-1}$. The solutions were stored at $-20^{\circ} \mathrm{C}$ until their administration.

The first experiments were performed to determine whether or not rhIL-3 increased the number of mast cells around the airways. Fourteen days after sensitization, rats received $50 \mu \mathrm{g}(\mathrm{n}=4)$ or $12.5 \mu \mathrm{g}(\mathrm{n}=2)$ of IL-3, respectively, subcutaneously b.i.d. for 4 days. Sensitized control rats $(n=6)$ were injected with vehicle at the same time intervals. The rats were killed by exsanguination after general anaesthesia and mast cells around the airways were counted.

The second experiments were performed to assess whether upregulation of mast cells via treatment with IL-3 increased the early airway response (EAR), inflammation, late airway response (LAR) and LT production after antigen challenge. Fourteen days after sensitization, rats received $50 \mu \mathrm{g}(\mathrm{n}=8)$ IL-3 subcutaneously b.i.d. for 4 days. Sensitized control rats $(n=12)$ were injected with vehicle at the same time intervals. The rats were then challenged with OA. As a reference for lung resistance over $8 \mathrm{~h}$, six sensitized rats were challenged with saline and their lung resistance measured for $8 \mathrm{~h}$.

\section{Determination of airway mast cell numbers}

Airway mast cell numbers were determined in six rats that received $30 \mathrm{nM}$ citric acid, four rats that received IL-3 $(50 \mu \mathrm{g})$ and two rats that received a lower dose of IL-3 $(12.5 \mu \mathrm{g})$ subcutaneously b.i.d. for 4 days. All rats were killed 1 day after the last IL-3 injection. The lungs were fixed by means of intrabronchial perfusion of $10 \%$
Carnoy's solution for $4 \mathrm{~h}$ at a pressure of $25 \mathrm{cmH}_{2} \mathrm{O}$ and then placed in $100 \%$ alcohol for $12 \mathrm{~h}$. Five-micron thick mid-sagittal sections were cut from lungs embedded in paraffin and stained with a modified May-Grünwald stain followed by a Giemsa stain. The airway epithelial basement membrane of each IL-3-treated or control rat was traced onto paper using a drawing tube attachment and then measured using a commercial digitizing program (Sigma Scan; Jandel Scientific, Montreal, Quebec, Canada). Airways with ratios of maximum internal diameter to minimum internal diameter $\geq 2$ were considered to be cut tangentially and therefore not analysed. The remaining airways were evaluated for the length of the epithelial basement membrane (PBM) and the number of mast cells in the wall of each airway was determined using oil immersion microscopy. Airways with a PBM $>2 \mathrm{~mm}$ were not present in all sections so analysis was restricted to airways $<2 \mathrm{~mm}$. For each animal, two to four airways with a PBM $<1 \mathrm{~mm}$ and two to four with a PBM of $<2$ but $>1 \mathrm{~mm}$ were analysed. The mean number of mast cells $\cdot \mathrm{mm}$ of basement membrane ${ }^{-1}$ for both airway sizes is presented for each rat. All morphometric measurements were performed by an observer ( $\mathrm{T}$. Du) blinded to the treatment status of the rats.

\section{Measurement of airway responses to ovalbumin chal- lenge}

Nineteen days after sensitization, rats were anaesthetized with urethane (1.1 g. $\mathrm{kg}^{-1}$ intraperitoneally). Blind orotracheal intubation was performed using a 6-cm-long polyethylene catheter (PE 240; Dickson, Pasppany, NJ, USA). Animals were placed on a heated blanket and rectal temperature was monitored throughout the experiment. Airway responses were determined from measurements of pulmonary resistance $(R \mathrm{~L})$, using methods that have previously been described in detail [18]. Briefly, the end of the endotracheal tube was inserted into a small Plexiglas box (OEM Medical Inc., Richmond, VA, USA) (volume $265 \mathrm{~mL}$ ) for the delivery of aerosols and measurement of airflow. A Fleisch No. 0 pneumotachograph coupled to a differential pressure transducer was attached to the other end of the box. Changes in oesophageal pressure were measured using a saline-filled catheter and a differential pressure transducer (Transpac II $($ ) Abbott, North Chicago, IL, USA) connected to the box. Transpulmonary pressure was computed as the difference between oesophageal and box pressure. $R \mathrm{~L}$ was calculated by means of multiple linear regression analysis using commercial software (RHT Infodat, Montreal, Canada). $R$ L is reported after subtraction of endotracheal tube resistance, which was measured as $0.11 \mathrm{cmH}_{2} \mathrm{O} \cdot \mathrm{mL} \cdot \mathrm{s}^{-1}$.

An aerosol of saline or OA $\left(5 \mathrm{mg} \cdot \mathrm{mL}^{-1}\right.$, for $\left.5 \mathrm{~min}\right)$ was generated using a Hudson nebulizer (RCI, Temecula, CA, USA) with an output of $0.18 \mathrm{~mL} \cdot \mathrm{min}^{-1}$ connected to one side port of the box. The box was flushed with a stream of fresh air between measurements in order to prevent the accumulation of $\mathrm{CO}_{2}$. Rats received either IL-3 $(50 \mu \mathrm{g})$ or vehicle for 4 days and were then challenged with aerosolized OA. The animals in both groups were killed $8 \mathrm{~h}$ after OA challenge. As a reference, six sensitized $\mathrm{BN}$ rats were challenged with saline and their lung mechanics were measured over $8 \mathrm{~h}$. 


\section{Measurement of biliary cysteinyl-leukotrienes}

Of the 20 OA-challenged rats, six control rats and six IL-3 treated rats were randomly selected and catheterized for the collection of bile and measurement of LTs as previously described [15]. Cysteinyl-LTs are excreted predominantly through the bile in rats [19]. The common bile duct was cannulated and samples were collected on ice in $1.5-\mathrm{mL}$ tubes (Eppendorf) under a stream of argon. The first bile sample was collected for $1 \mathrm{~h}$ before OA challenge and considered as baseline. After OA challenge, bile samples were collected at 1-h intervals for $8 \mathrm{~h}$. The samples were stored at $-70^{\circ} \mathrm{C}$ until analysis by means of reverse phase-high pressure liquid chromatography (RP$\mathrm{HPLC}$ ) and radioimmunoassay for $\mathrm{LTC}_{4}, \mathrm{LTD}_{4}, \mathrm{LTE}_{4}$ and $N$-acetyl-LTE 4 .

The total amounts of cysteinyl-LTs in bile were calculated by adding the amounts (in pmol per time period) for $\mathrm{LTC}_{4}, \mathrm{LTD}_{4}, \mathrm{LTE}_{4}$ and $N$-acetyl-LTE 4 . The elevated levels of cysteinyl-LTs appearing in bile during the first hour after OA inhalation were considered to result from the EAR. The bile collected 3-8 h after challenge was considered to result from the LAR.

\section{Determination of pulmonary leukocyte numbers}

After the final measurement of $R \mathrm{~L}$, the rats were exsanguinated by means of puncture of the left ventricle. Blood was kept in a heparinized tube for analysis of lymphocyte subsets via flow cytometry. Balanced salt solution was injected into the right ventricle to flush the pulmonary vasculature. The lungs were dissected from the chest and mediastinal structures, washed in balanced salt solution, and lung mincing and digestion performed as previously described [20]. The cellular differential was assessed on a Wright's Giemsa-stained slide by counting 200 cells using oil immersion microscopy.

\section{Isolation and staining of lymphocyte subsets}

Mononuclear cells were isolated from heparinized peripheral blood by standard Ficoll-Hypaque methods for flow cytometry. The isolated cells or the cells obtained after lung digestion were washed with Hank's balanced salt solution (HBSS) and incubated with the monoclonal antibodies W3/25 (CD4), OX8 (CD8) or OX33 (B cell) for $30 \mathrm{~min}$, washed and incubated with fluorescein isothiocyanate (FITC)-conjugated goat anti-mouse IgG monoclonal antibody for a further $20 \mathrm{~min}$ and washed and fixed as previously described [20]. Viability was determined by adding $1 \mu \mathrm{g} \cdot \mathrm{mL}^{-1}$ propidium iodide to unfixed specimens and averaged $98 \pm 2 \%$. Controls consisted of cells incubated with polyclonal antibodies obtained from mouse ascites fluid and averaged $2 \pm 0.6 \%$.

\section{Statistical analyses}

Data were analysed, using the Instat program, by means of unpaired t-tests or, when variances were considered to be unequal, by an F-test or the Mann-Whitney U-test. Analysis of variance (ANOVA) was performed when comparing the results from three groups of rats. A p-value $<0.05$ was considered significant. The data are expressed throughout as mean \pm SEM.

\section{Chemicals}

Ovalbumin, collagenase, Wright's Giemsa stain, MayGrünwald Giemsa, propidium iodide, chloroform and acetic acid were purchased from Sigma Chemicals (St Louis, MO, USA); B. pertussis vaccine was purchased from Connaught Laboratories. (Willowdale, Ontario, Canada). W3/25, OX8 and OX33 monoclonal antibodies were purchased from Dimension Labs (Mississauga, Ontario, Canada); FITC-conjugated goat anti-mouse monoclonal antibody was obtained from Organon Tecnica (Scarborough, Ontario, Canada). Foetal bovine serum, penicillin, streptomycin, L-glutamine, nonessential amino acids, RPMI 1640 medium and trypan blue were obtained from GIBCO Laboratories (New York, USA). Ficoll-Hypaque was obtained from Pharmacia (Montreal, Quebec, Canada).

\section{Results}

\section{Effects of interleukin-3 on airway mast cell numbers}

The mean number of mast cells in airways $<2 \mathrm{~mm}$ obtained from the IL-3 or vehicle-treated rats were assessed $(n=12$ rats, table 1$)$. Treatment of rats with 12.5 or $50 \mu \mathrm{g}$ IL-3 increased the mean number of mast cells.mm of basement membrane ${ }^{-1} 2.3$-fold in airways with a PBM of $<1 \mathrm{~mm}$ and 2.0-fold in the airways with a PBM of $>1$ but $<2 \mathrm{~mm}$. There was no difference in the number of mast cells between 12.5 and $50 \mu \mathrm{g}$ IL-3-treated rats.

\section{Early and late airway responses after ovalbumin chal- lenge}

Baseline values of $R \mathrm{~L}$ (after saline inhalation) were similar in rats treated with $50 \mu \mathrm{g}$ IL-3 and vehicle $(0.13 \pm$ 0.03 versus $\left.0.12 \pm 0.02 \mathrm{cmH}_{2} \mathrm{O} \cdot \mathrm{mL}^{-1} \cdot \mathrm{s}^{-1} ; \mathrm{p}>0.8\right)$. Two 50 $\mu \mathrm{g}$ IL-3-treated rats died 4 and $5 \mathrm{~h}$ after OA challenge and were excluded from further analysis, although their results were included in the analysis of EAR. The percentage increase in RL during EAR and LAR, measured as the area under the curve of $R \mathrm{~L}$ versus time 3-8 h after challenge, was not significantly different in animals which received $50 \mu \mathrm{g}$ IL-3 or controls (EAR $174 \pm 37$ versus $220 \pm 23 \%$, $\mathrm{p}>0.2$; LAR: $26.1 \pm 9.8$ versus $19.7 \pm 5.7 \%, \mathrm{p}>0.5$ ).

Table 1. - Effect of interleukin (IL)-3 on mast cell density in the airways

\begin{tabular}{|c|c|c|c|c|}
\hline \multirow[b]{2}{*}{ IL-3 dose $\mu \mathrm{g}$} & \multicolumn{2}{|c|}{ PBM $<1 \mathrm{~mm}$} & \multicolumn{2}{|c|}{ PBM $>1$ but $<2 \mathrm{~mm}$} \\
\hline & Vehicle & IL-3 & Vehicle & IL-3 \\
\hline \multirow[t]{2}{*}{12.5} & 1.26 & 3.55 & 2.79 & 6.42 \\
\hline & 2.13 & 4.41 & 3.33 & 6.67 \\
\hline \multirow[t]{4}{*}{50} & 1.83 & 2.61 & 2.22 & 6.13 \\
\hline & 1.62 & 4.14 & 2.92 & 4.92 \\
\hline & 2.21 & 5.01 & 3.10 & 5.82 \\
\hline & 1.51 & 4.78 & 3.80 & 5.61 \\
\hline Mean & 1.76 & $4.09 * * *$ & 3.03 & $5.81 * * *$ \\
\hline SEM & 0.15 & 0.36 & 0.22 & 0.36 \\
\hline
\end{tabular}

Values represent mean number of mast cells.mm of basement membrane $^{-1}$ for individual rats. $* * *: p<0.001$ compared with vehicle. PBM: length of the epithelial basement membrane. 
Cellular influx and lymphocyte subsets after antigen challenge

No significant difference was found in the total number of pulmonary leukocytes between $50 \mu \mathrm{g}$ IL-3-treated and control rats $\left(14.1 \pm 4.6 \times 10^{6}\right.$ versus $23.3 \pm 3.2 \times 10^{6}$ cells, $\mathrm{p}=0.09$, Mann-Whitney U-test). The percentage of eosinophils in the lungs was significantly higher in IL-3-treated rats $(5.5 \pm 0.5$ versus $1.7 \pm 0.4 \%, \mathrm{p}<0.002)$. Eosinophil number was also significantly increased in IL-3-treated rats $\left(0.772 \pm 0.23 \times 10^{6}\right.$ versus $0.377 \pm 0.12 \times 10^{6}$ cells, $\left.\mathrm{p}=0.03\right)$. The percentages and total cell counts for neutrophils, lymphocytes and macrophages in the lungs were similar in both groups. Lymphocyte subsets in the lungs and blood were also similar in IL-3-treated and control rats (fig. 1).

Biliary cysteinyl-leukotrienes during the early and late airway response

Baseline total LTs concentrations in IL-3-treated rats were not significantly different from the values obtained in control rats $\left(2.9 \pm 0.65\right.$ versus $5.2 \pm 0.8 \mathrm{pmol} \cdot \mathrm{h}^{-1}, \mathrm{p}=0.08$, Mann-Whitney U-test). Total LT production increased significantly in both groups after OA challenge. During the EAR, LT production increased by $5.4 \pm 1.2$ and $5.4 \pm 2.1$ $\mathrm{pmol} \cdot \mathrm{h}^{-1}$ in the IL-3-treated and control rats, respectively $(\mathrm{p}<0.05$ versus baseline). During the LAR, LT production increased by $5.3 \pm 1.5$ and $5.6 \pm 1.4 \mathrm{pmol} \cdot \mathrm{h}^{-1}$ in the control and IL-3-treated rats, respectively $(\mathrm{p}<0.01$ versus baseline). No significant difference was found in the increase in total bile LTs during either EAR or LAR between IL-3treated rats or controls. The predominant LT in the bile fluid was $N$-acetyl-LTE 4 in both groups. No marked differences were found in the individual bile LT species between the two groups (fig. 2). There was a higher level of $\mathrm{LTE}_{4}$ at $5-6 \mathrm{~h}$ after challenge in the IL-3-treated animals, but the significance of this particular observation is uncertain in view of the lack of similar changes in other LTs.

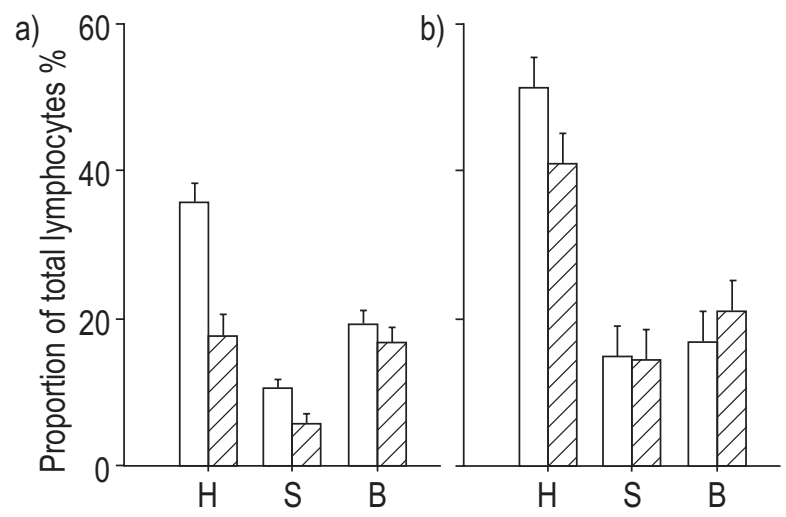

Fig. 1. - Effects of interleukin (IL)-3 on: a) lung; and b) blood lymphocyte subsets $8 \mathrm{~h}$ after ovalbumin (OA) challenge. Brown Norway rats were challenged with OA 19 days after sensitization and killed $8 \mathrm{~h}$ after OA challenge. Lymphocyte surface antigens were assessed on cells obtained from the lungs or blood as described in the Materials and methods. Animals received either IL-3 ( $\mathbb{Z}, 50 \mu \mathrm{g}$ b.i.d., $\mathrm{n}=6)$ or vehicle $(\square, n=12)$ for 4 days before OA challenge. Vertical bars represent mean \pm SEM. No results were significant. H: helper cells; S: suppressor cells; B: B cells. a)

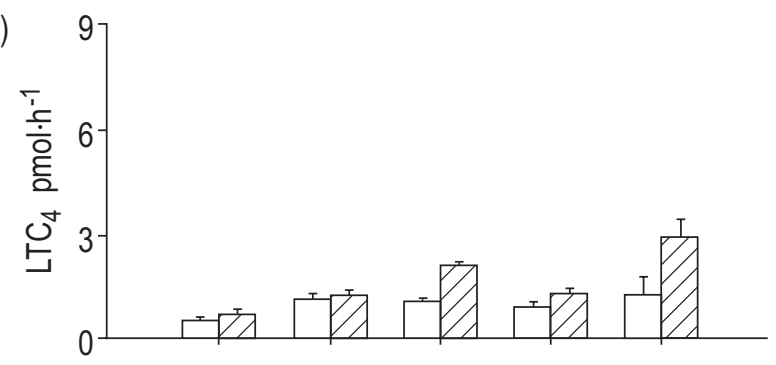

b)

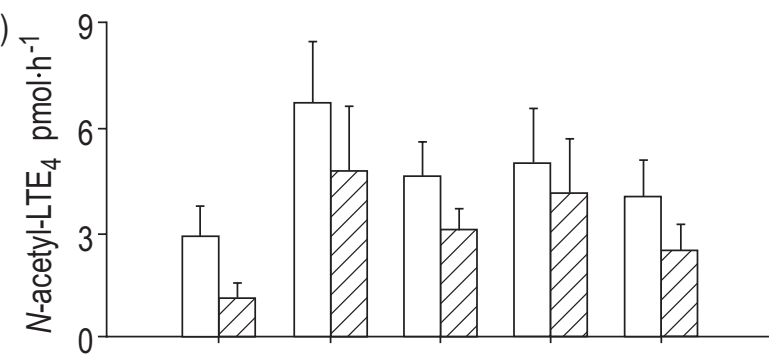

c)

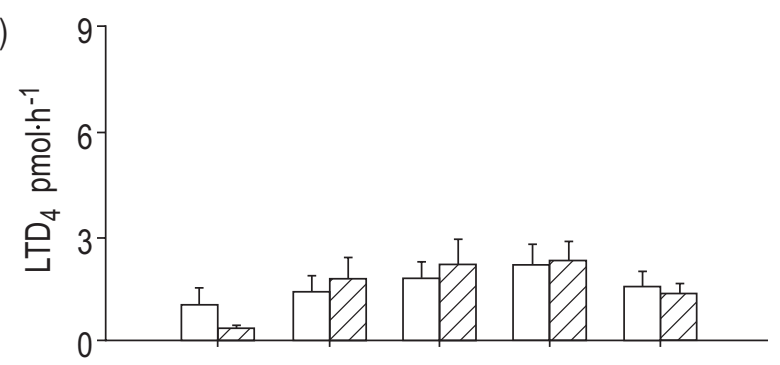

d)

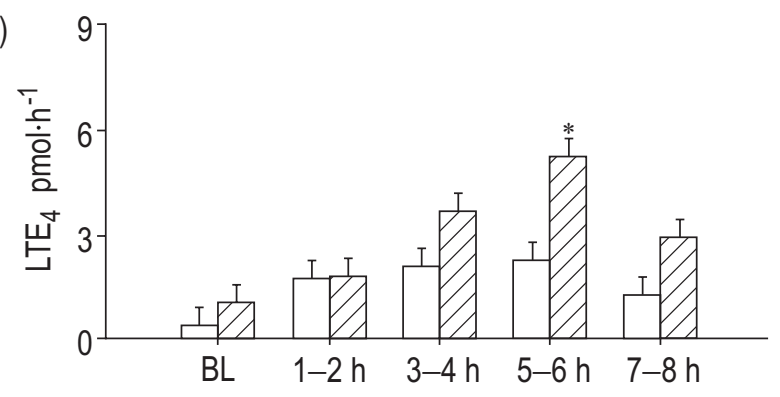

Fig. 2. - Effects of interleukin (IL)-3 on biliary cysteinyl-leukotriene (LT) production after ovalbumin challenge. a) $\mathrm{LTC}_{4}$; b) $N$-acetyl-LTE ; $_{4}$ c) $\mathrm{LTD}_{4}$; and d) $\mathrm{LTE}_{4}$. Brown Norway rats were challenged 19 days after sensitization, after receiving IL-3 $(\mathbb{Z}, 50 \mu \mathrm{g}, \mathrm{n}=4)$ or vehicle $(\square, \mathrm{n}=6)$ b.i.d. for 4 days. Biliary cysteinyl-LTs were assessed as described in the Materials and methods. BL: baseline. ${ }^{*}: \mathrm{p}<0.05$ compared with vehicle.

\section{Discussion}

The administration of rhIL-3 significantly increased the numbers of certain inflammatory cells in the lungs of $\mathrm{BN}$ rats. The pattern of inflammation was consistent with the in vitro properties of IL-3 [6, 8], affecting mast cells and eosinophils only. However, the presence of increased inflammatory cell numbers did not significantly affect the magnitude of the OA-induced EAR and LAR nor the increases in levels of biliary LTs following OA challenge.

Mast cells play an important role in IgE-mediated allergic airway disease by releasing bronchoconstrictive and pro-inflammatory mediators after bridging of their $\mathrm{Fc}_{\varepsilon} \mathrm{R}_{1}$ receptors $[6,21,22]$. Anti-IgE-induced airway responses were not present in mast cell-deficient mice, but could be restored via the mast cells from mast cell positive mice 
[22]. Experiments performed in vitro have shown that IL3 is capable of promoting the growth and differentiation of mast cell progenitors [7]. As expected, therefore, IL-3 induced significant increases in mast cell numbers in the airways of the $\mathrm{BN}$ rat. However, the changes in $R \mathrm{~L}$ and the increase in bile LT production evoked by OA challenge were comparable to those in controls. The critical role of mast cells in IgE-mediated reactions is well established. For example, treatment of mast cell-deficient mice with stem cell factor induced mast cell hyperplasia and re-established IgE-dependent anaphylaxis [23]. However, the quantitative relationship between mast cell numbers and the magnitude of anaphylaxis is less clear, as evidenced by the fact that chronic treatment of normal mice with stem cell factor did not increase and, under some circumstances, even decreased the severity of IgEdependent anaphylaxis despite mast cell hyperplasia. Likewise, NAGAI et al. [24] found that pretreatment with IL-3 did not enhance antigen-induced human tracheal muscle contraction and histamine release from lung tissue. The absence of an increase in EAR and LAR after upregulation of mast cell numbers may relate to immaturity of the mast cells present, downregulation of the activity of these cells, or the possibility that mast cells are only a trigger for the EAR and LAR and are not the sole determinants of the magnitude of physiological changes.

The mast cell subset, mucosal or connective tissue [25, 26], that is important to allergic airway responses has not been established. Although it is not known which mast cells predominate in the airways of $\mathrm{BN}$ rats, Gото et al. [26] showed that, in normal Lewis rats, most lung mast cells are of the connective tissue type. It is likely that the increase in mast cells in the current experiments were of the mucosal type, since only IL-3 was administered to these rats and it has been shown that a combination of IL3 and IL-4 at least is necessary for connective tissue mast cell proliferation [25]. Mucosal mast cells may, thus, not be important in the EAR and LAR after OA challenge. This hypothesis is supported by results found in human asthmatics [14]. Although mast cells were increased in asthmatic subjects' airways, there was no correlation between IL-3 and eosinophil number and activity, metachromatic cell number, airway responsiveness and the severity of the late asthmatic response [14].

In the present experiments, IL-3 caused an increase in eosinophilia 8-h after OA challenge. The effects of IL-3 are not limited to mast cells but include a range of actions on eosinophils [8, 27]. IL-3 prolongs eosinophil survival [27] and promotes the early stages of eosinophil differentiation [8]. IL-5 appears to be necessary for the late stages of eosinophil differentiation [28]; thus, both cytokines are required for the proliferation of eosinophils to occur in vitro. The mechanism for the increase in eosinophil number in the lungs is unknown. It may reflect an increase in influx after challenge or an increase in eosinophils induced by pretreatment with IL-3 before challenge. Although many of the actions of IL-3 on eosinophils are dependent on the concomitant presence of IL-5, it is possible that sufficient IL-5 is present in the airways in vivo to facilitate the actions of IL-3 on the eosinophil.

Despite the increase in eosinophil number in the lungs, they did not affect the physiological response after OA challenge. This may be due to immaturity of the eosinophils, downregulation of their activity, or eosinophils not participating in the EAR and LAR that follow OA challenge in $\mathrm{BN}$ rats. The latter is not unexpected because rodent eosinophils do not produce cysteinyl-LTs, which are critical to the airway responses to allergen in the rat [29].

In conclusion, subcutaneous administration of recombinant human interleukin-3 increased inflammation in the lungs of rats. The most notable effects were on mast cell and eosinophil numbers, to the same extent as that reported previously after administration of recombinant human interleukin-2 [18]. Although the effects of recombinant human interleukin-3 appeared to be specific, nonspecific effects cannot be ruled out since recombinant human interleukin-3 and rat interleukin-3 are not homologous. Increased inflammation was not followed by increased physiological changes or leukotriene production after ovalbumin challenge. It seems unlikely, therefore, that interleukin-3 is a critical cytokine in the early and late allergic responses to ovalbumin challenge.

\section{References}

1. Burrows B, Martinez FD, Halonen M, Barbee RA, Cline MG. Association of asthma with serum IgE levels and skin-test reactivity to allergens. N Engl J Med 1989; 320: 271-277.

2. Jeffery PK, Wardlaw AJ, Nelson FC, Collins JV, Kay AB. Bronchial biopsies in asthma: an ultrastructural, quantitative study and correlation with hyperreactivity. Am Rev Respir Dis 1989; 140: 1745-1753.

3. Kay AB. Asthma and inflammation. J Allergy Clin Immunol 1991; 87: 893-910.

4. Yang JP, Renzi PM. Interleukin-2 and lymphocyte-induced eosinophil proliferation and survival in asthmatic patients. J Allergy Clin Immunol 1993; 91: 792-801.

5. Bentley AM, Meng Q, Robinson DS, Hamid Q, Kay AB, Durham SR. Increases in activated T lymphocytes, eosinophils, and cytokine mRNA expression for interleukin5 and granulocyte/macrophage colony-stimulating factor in bronchial biopsies after allergen inhalation challenge in atopic asthmatics. Am J Respir Cell Mol Biol 1993; 8: 3542.

6. Ihle JN, Keller J, Oroszlan S, et al. Biologic properties of homogeneous interleukin 3. I. Demonstration of WEHI-3 growth factor activity, mast cell growth factor activity, $\mathrm{p}$ cell-stimulating factor activity, colony-stimulating factor activity, and histamine-producing cell-stimulating factor activity. J Immunol 1983; 131: 282-287.

7. Haig DM, McMenamin C, Redmond J, et al. Rat IL-3 stimulates the growth of rat mucosal mast cells in culture. Immunology 1988; 65: 205-211.

8. Sanderson CJ, Warren DJ, Strath M. Identification of a lymphokine that stimulates eosinophil differentiation in vitro: its relationship to interleukin 3 , and functional properties of eosinophils produced in cultures. J Exp Med 1985; 162: 60-74.

9. Sugiyama H, Eda R, Hopp RJ, Bewtra AK, Townley RG. Importance of IL-3 on histamine release from human basophils. Ann Allergy 1993; 71: 391-395.

10. Lantero S, Sacco O, Scala C, Rossi GA. Stimulation of blood mononuclear cells of atopic children with the relevant allergen induces the release of eosinophil chemotaxins such as IL-3, IL-5, and GM-CSF. J Asthma 1997; 34: 141-152.

11. Lai CK, Ho SS, Chan CH, Leung R, Lai KN. Gene expression of interleukin-3 and granulocyte macrophage 
colony-stimulating factor in circulating CD4+ T cells in acute severe asthma. Clin Exp Allergy 1996; 26: 138-146.

12. Humbert $\mathrm{M}$, Ying $\mathrm{S}$, Corrigan $\mathrm{C}$, et al. Bronchial mucosal expression of the genes encoding chemokines RANTES and MCP-3 in symptomatic atopic and nonatopic asthmatics: relationship to the eosinophil-active cytokines IL-5, granulocyte macrophage-colony-stimulating factor, and IL-3. Am J Respir Cell Mol Biol 1997; 16: 1-8.

13. Wallaert B, Desreumaux P, Copin MC, et al. Immunoreactivity for interleukin 3 and 5 and granulocyte/macrophage colony-stimulating factor of intestinal mucosa in bronchial asthma. J Exp Med 1995; 182: 1897-1904.

14. Woolley KL, Adelroth E, Woolley MJ, et al. Interleukin-3 in bronchial biopsies from nonasthmatics and patients with mild and allergen-induced asthma. Am J Respir Crit Care Med 1996; 153: 350-355.

15. Martin JG, Xu L-J, Toh M-Y, Olivenstein R, Powell WS. Leukotrienes in bile during the early and the late airway responses after allergen challenge of sensitized rats. $\mathrm{Am}$ Rev Respir Dis 1993; 147: 104-110.

16. Foster A, Letts G, Charleson S, Fitzsimmons B, Blacklock B, Rokach J. The in vivo production of peptide leukotrienes after pulmonary anaphylaxis in the rat. $J$ Immunol 1988; 141: 3544-3550.

17. Renzi PM, Du T, Sapienza S, Wang NS, Martin JG. Acute effects of interleukin-2 on lung mechanics and airway responsiveness in rats. Am Rev Respir Dis 1991; 143: 380385.

18. Renzi PM, Sapienza S, Waserman S, et al. Effect of interleukin-2 on the airway response to antigen in the rat. Am Rev Respir Dis 1992; 146: 163-169.

19. Hagmann W, Denzlinger C, Rapp S, Weckbecker G, Keppler D. Identification of the major endogenous leukotriene metabolise in the bile of rats as $N$-acetyl leukotriene $\mathrm{E}_{4}$. Prostaglandins 1986; 31: 239-251.

20. Renzi PM, Olivenstein R, Martin JG. Inflammatory cell populations in the airways and parenchyma after antigen challenge in the rat. Am Rev Respir Dis 1993; 147: 967974.

21. Kaliner M. Asthma and mast cell activation. J Allergy Clin Immunol 1989; 83: 510-520.
22. Martin TR, Galli SJ, Katona IM, Drazen JM. Role of mast cells in anaphylaxis: evidence for the importance of mast cells in the cardiopulmonary alterations and death induced by anti-IgE in mice. J Clin Invest 1989; 83: 13751383.

23. Ando A, Martin TR, Galli SJ. Effects of chronic treatment with the c-kit ligand, stem cell factor, on immunoglobulin E-dependent anaphylaxis in mice. Genetically mast celldeficient $\mathrm{Sl} / \mathrm{Sld}$ mice acquire anaphylactic responsiveness, but the congenic normal mice do not exhibit augmented responses. J Clin Invest 1993; 92: 1639-1649.

24. Nagai H, Suda H, Iwama T, Daikoku M, Yanagihara Y, Koda A. Effect of NZ-107, a newly synthesized pyridazinone derivative, on antigen-induced contraction of human bronchial strips and histamine release from human lung fragments or leukocytes. Int Arch Allergy Immunol 1992; 98: 57-63.

25. Tsuji K, Nakahata T, Takagi M, et al. Effects of interleukin-3 and interleukin-4 on the development of "connective tissue-type" mast cells: interleukin-3 supports their survival and interleukin-4 triggers and supports their proliferation synergistically with interleukin-3. Blood 1990; 75: 421-427.

26. Goto T, Befus D, Low R, Bienenstock J. Mast cell heterogeneity and hyperplasia in bleomycin-induced pulmonary fibrosis of rats. Am Rev Respir Dis 1984; 130: 797-802.

27. Tai PC, Sun L, Spry CJ. Effects of IL-5, granulocyte/ macrophage colony-stimulating factor (GM-CSF) and IL3 on the survival of human blood eosinophils in vitro. Clin Exp Immunol 1991; 85: 312-316.

28. Ema H, Suda T, Nagayoshi K, Miura Y, Civin CI, Nakauchi $\mathrm{H}$. Target cells for granulocyte colony-stimulating factor, interleukin-3, and interleukin-5 in differentiation pathways of neutrophils and eosinophils. Blood 1990; 76: 1956-1961.

29. Yu W, Xu LJ, Martin JG, Powell WS. Cellular infiltration and eicosanoid synthesis in Brown Norway rat lungs after allergen challenge. Am J Respir Cell Mol Biol 1995; 13: 477-486. 